\title{
Effect of Number of Suckers per Hill on Growth and Yield of Banana cv. Malbhog (AAB) in Ratoon Crop
}

\author{
Rupshree Borah $^{1 *}$, Dharindra Nath Hazarika ${ }^{1}$, Supriya Langthasa ${ }^{1}$ and \\ Dorodi Priyam Duarah ${ }^{2}$
}

\author{
${ }^{1}$ Department of Horticulture, B. N. College of Agriculture, Assam Agricultural University, \\ Biswanath Chariali-784176, Assam, India \\ ${ }^{2}$ Krishi Vigyan Kendra, Kamrup, Assam Agricultural University, Kahikuchi, \\ Guwahati -781017, Assam, India
}

*Corresponding author

\section{A B S T R A C T}

\begin{tabular}{|l|}
\hline K e y w o r d s \\
Planting density, Spacing, \\
$\begin{array}{l}\text { Malbhog, Ratoon crop, } \\
\text { Banana sucker, Growth, } \\
\text { Yield }\end{array}$ \\
\hline Article Info \\
\hline $\begin{array}{l}\text { Accepted: } \\
15 \text { September } 2018 \\
\text { Available Online: } \\
\text { 10 October } 2018\end{array}$ \\
\hline
\end{tabular}

\section{Introduction}

Banana (Musa spp.) is one of the most important staple food and starchy fruit crops of the world and India ranks first in both area and production in world scenario. Banana is considered to be the most nutritious fruit available though out the year. Botanically, banana is a monocotyledonous, monocarpic, herbaceous plant belonging to the section Eumusa under the family Musaceae (Purseglove, 1976). Though area under banana production has been increasing in India but the

\begin{abstract}
An experiment was carried out at ICR farm, Department of Horticulture during 2015-2017 to study the effect of number of suckers per hill on growth, yield and quality of banana cv. Malbhog $(\mathrm{AAB})$ in ratoon crop. The treatments were $\mathrm{T}_{1}$ (mother plant +1 sucker), $\mathrm{T}_{2}$ (mother plant +2 suckers), $\mathrm{T}_{3}$ (mother plant +3 suckers), and $\mathrm{T}_{4}$ (mother plant +4 suckers) with two spacing $-S_{1}(2.1 \mathrm{~m} \times 2.1 \mathrm{~m})$ and $S_{2}(2.5 \mathrm{~m} \times 2.5 \mathrm{~m})$ for all the treatments. One treatment with recommended package of practices (control) was also included in the experiment. Nine treatment combinations were laid out in RBD with three replications. Growth and yield of Malbhog banana and quality of fruits were significantly influenced by different treatments and spacing. Among the treatments, $S_{1} T_{1}$ (mother plant +1 sucker/plant recorded higher yield (19.73 t/ha), shorter period from harvesting of first crop to harvesting of first ratoon crop (72.92 days) and benefit-cost ratio (4.75).
\end{abstract}

total production, productivity and quality of the fruits have been found to be in reducing trend. This might be due to poor management of suckers, spacing, fertilization, irrigation, pests and diseases. In recent years, more emphasis is being given to higher productivity of banana per unit area with better quality by adopting various means. One of such methods is high density planting which depends on variety, method of cultivation, the height and spread of banana plant. Among the different cultural practices, desuckering is one of the important practices which influence the size of 
the fingers and bunch weight of banana. The commercial cultivation of banana in Assam has gained momentum since last one decade. But the growers in Assam rarely follow the practice of desuckering as per recommended package of practices. The majority of the farmers in Assam allow all the suckers to grow along with the mother plants. If all the suckers which arise from the stool are allowed to grow, bunches become smaller with poor quality and some plants may not bear fruit at all (Seifu, 2003). As per opinion of banana growers of Assam, if desuckering is practiced then the period from harvesting of first crop to harvesting of ratoon crop become longer and it affects the economic condition of the small and marginal growers. Therefore, the growers allow the suckers to grow along with the mother plants to get return earlier from the subsequent ratoon crops.

\section{Materials and Methods}

An experiment was carried out at instructional cum experimental farm, Department of Horticulture, Biswanath College of Agriculture, Assam Agricultural University, Biswanath Chariali during 2015-2017 to "study the effect of number of suckers per hill on growth, yield and quality of banana cv. Malbhog (AAB) in ratoon crop". The treatments were $\mathrm{T}_{1}$ (mother plant +1 sucker), $\mathrm{T}_{2}$ (mother plant +2 suckers), $\mathrm{T}_{3}$ (mother plant +3 suckers), and $\mathrm{T}_{4}$ (mother plant +4 suckers). There were two spacing - $\mathrm{S}_{1}(2.1 \mathrm{~m} \mathrm{x}$ $2.1 \mathrm{~m})$ and $\mathrm{S}_{2}(2.5 \mathrm{~m} \times 2.5 \mathrm{~m})$ for all the treatments. One treatment with recommended package of practices (control) was also included in the experiment. Nine treatment combinations were laid out in RBD with three replications. The data were collected on pseudostem height which is from the ground level to the point of interaction of the youngest leaves and second leaf axils, pseudostem girth at $30 \mathrm{~cm}$ above the ground level, number of functional leaves, LAI, phyllochron, period from first sucker emergence to shooting, shooting-harvest interval, duration from harvesting of first crop to harvesting of first ratoon crop, crop duration, number of hands, number of fingers, bunch weight and yield of first crop and first ratoon crop.

\section{Results and Discussion}

Pseudostem height and girth determine the growth and development of banana plant. Banana pseudostem is constituted of tightly packed with leaf sheaths which is functionally the trunk of the plant responsible for support of the bunch. The growth of the pseudostem is mainly determined by the growth of the leaf sheaths. In the present study, the plant height and girth gradually increased from vegetative stage to shooting irrespective of the treatments. The plant height recorded at vegetative stage and at shooting increased with the increase number of suckers per hill at both the spacing. The highest plant height of $146.49 \mathrm{~cm}$ and $293.99 \mathrm{~cm}$ were recorded in $\mathrm{T}_{4}$ (mother plant +4 suckers) at vegetative stage and at shooting, respectively; while $\mathrm{T}_{1}$ (mother plant +1 sucker) recorded the lowest pseudostem height of $109.11 \mathrm{~cm}$ and 279.56 $\mathrm{cm}$ at vegetative stage and at shooing, respectively. It was observed that the penetration of sunlight through the banana plants gradually decreased with the increase in number of suckers per hill. An increase in pseudostem height with increasing number of suckers might be due to the increased plant population per unit area which provided less space for individual plant and in search of sunlight perhaps made the plant to grow upright resulting in tall growth. The present investigation is in conformity with the reports of Chaudhuri and Baruah (2010) who recorded the highest pseudostem height in plants when three suckers were planted in the same pit with a spacing of $2.0 \mathrm{~m} \times 3.0 \mathrm{~m}$. The present findings is also in support of the results of Mahdi et al., (2014) who elaborated that at 
flowering time of the main crop, the height of the main plants and the first follower increased progressively with sucker management.

At shooting stage, pseudostem girth gradually decreased with increase in the number of suckers per plant. It might be due to the uptake of nutrients available in soil by the main plant and the developing suckers simultaneously. Besides, recommended dose of nutrients for Assam at the rate of $110 \mathrm{~g} \mathrm{~N}, 33 \mathrm{~g} \mathrm{P}_{2} \mathrm{O}_{5}$ and $330 \mathrm{~g} \mathrm{~K}_{2} \mathrm{O}$ per plant were applied to each mat which might have been shared by the mother plant and the suckers. Hidoto (2009) opined from his study that suckers suffered from root competition for moisture and nutrients when allowed to grow together with planted banana and thus it significantly reduced the pseudostem girth of banana as the suckers were not removed. Higher pesudostem height and girth observed at shooting in wider spacing $\left(\mathrm{S}_{2}\right)$ as compared to closer spacing $\left(\mathrm{S}_{1}\right)$ might be due to the competition for sunlight, nutrients, assimilates and moisture. These results were corroborate with the findings of Sarrwy et al., (2012) who reported that girth recorded in plants without sucker or with one sucker were higher than the multiple of three suckers plant.

The role of leaf parameters such as, number of leaves produced, number of functional leaves retained at shooting is crucial in determining the yield potential. A banana crop should produce sufficient number of leaves to harness the light energy and synthesize adequate photosynthates for biomass production. In the present investigation, the number of functional leaves per plant was found to be higher at shooting stage in all the treatments as compared to that of vegetative stage and at harvest. The number of leaves per plant decreased with the increase in number of suckers allowed to grow with mother plants in all the stages of observation. Similar trend was also observed by Robinson and Nel (1989) who reported that reduction in leaf emergence was due to inter mat competition.

The results of the present investigation revealed that retention of functional leaves in the plants was higher at shooting than at vegetative and at harvesting. The number of functional leaves retained in the plants varied from 7.94 to 9.21 at shooting in different treatments. Robinson et al., (1992) found that retention of 8.0 numbers of leaves at flower emergence was sufficient to achieve maximum yield and finger length in banana. The plants under control (recommended practice) where no sucker was allowed to grow till shooting produced higher number of functional leaves. The present result is in conformity of the results of Gogoi et al., (2015) who remarked that higher number of functional leaves in plants with one was due to less competition for soil moisture, nutrients and light intensity.

Leaf is the main site of photosynthetic activity and hence the estimation of leaf area index is very important in the growth analysis of crop plants to get an idea about productivity. The data of the leaf area index of all the treatments in the present study showed an increasing trend from vegetative stage to shooting stage which might be due to the production of bigger size leaves at shooting than at vegetative stage. Simmonds (1966) also reported that leaves attained maximum size towards flowering in banana.

Phyllochron, planting-shooting interval, shooting-harvest interval and crop duration were considered as phenological characters. All these characters of banana plants are correlated to each other. The present study showed an interval between two successive leaves ranging from 8.29 days $\left(\mathrm{S}_{2} \mathrm{~T}_{1}\right)$ to 9.53 days $\left(\mathrm{S}_{1} \mathrm{~T}_{4}\right)$ indicating better growth of the plants (Table 1-6). 
Table.1 Pseudostem height and girth of first ratoon crop

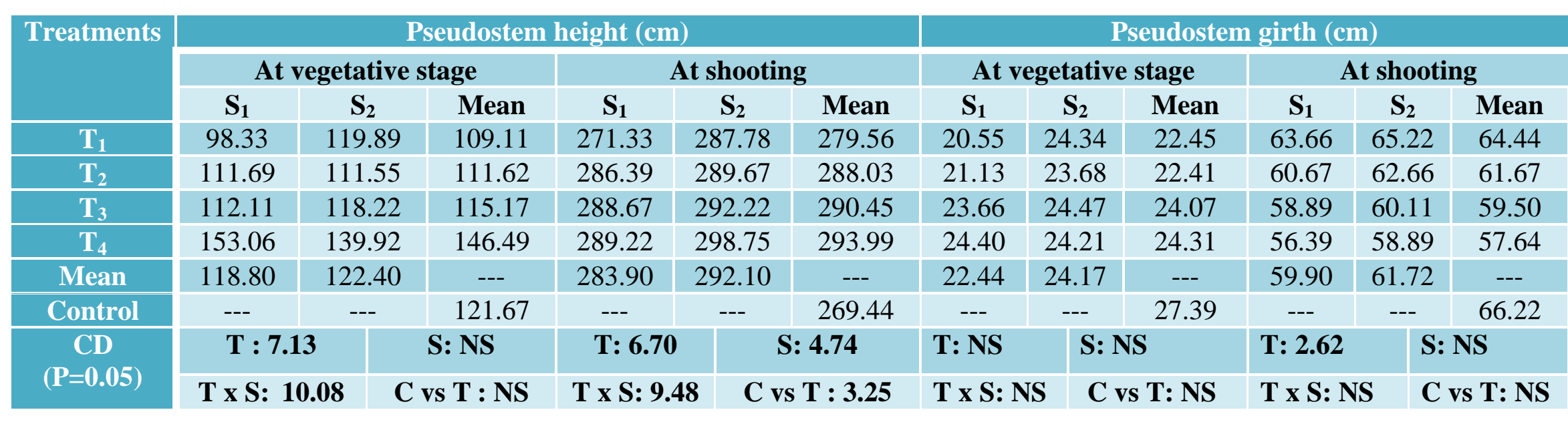

Table.2 Number of functional leaves per plant at different stage

\begin{tabular}{|c|c|c|c|c|c|c|c|c|c|}
\hline \multirow[t]{3}{*}{ Treatments } & \multicolumn{9}{|c|}{ Number of functional leaves per plant } \\
\hline & \multicolumn{3}{|c|}{ At vegetative stage } & \multicolumn{3}{|c|}{ At shooting } & \multicolumn{3}{|c|}{ At harvest } \\
\hline & $\mathbf{S}_{1}$ & $\mathbf{S}_{\mathbf{2}}$ & Mean & $\mathbf{S}_{1}$ & $\mathbf{S}_{\mathbf{2}}$ & Mean & $\mathbf{S}_{1}$ & $\mathbf{S}_{2}$ & Mean \\
\hline $\mathrm{T}_{2}$ (two suckers/plant) & 7.22 & 7.11 & 7.17 & 8.39 & 9.18 & 8.78 & 3.50 & 3.00 & 3.25 \\
\hline $\mathrm{T}_{\mathbf{3}}$ (three suckers/plant) & 7.00 & 6.55 & 6.78 & 7.85 & 8.67 & 8.26 & 3.42 & 2.78 & 3.10 \\
\hline Mean & 7.47 & 6.79 & --- & 8.29 & 8.81 & --- & 3.42 & 2.90 & --- \\
\hline Control & --- & --- & 8.75 & --- & --- & 9.33 & --- & --- & 3.83 \\
\hline \multirow[t]{2}{*}{$\mathrm{CD}(\mathrm{P}=0.05)$} & \multicolumn{2}{|c|}{$\mathrm{T}: \mathbf{0 . 6 0}$} & S: 0.43 & \multicolumn{2}{|c|}{$\mathrm{T}: 0.54$} & $S: 0.38$ & \multicolumn{2}{|c|}{ T: NS } & S: 0.22 \\
\hline & \multicolumn{2}{|c|}{$\mathbf{T} \times \mathbf{S}: \mathbf{N S}$} & C vs T : NS & \multicolumn{2}{|c|}{ T x S: NS } & C vs T: 0.77 & \multicolumn{2}{|c|}{ T $x$ S: NS } & C vs T: 0.43 \\
\hline
\end{tabular}


Table.3 Leaf area index (LAI) per plant at different growth stages of first ratoon crop

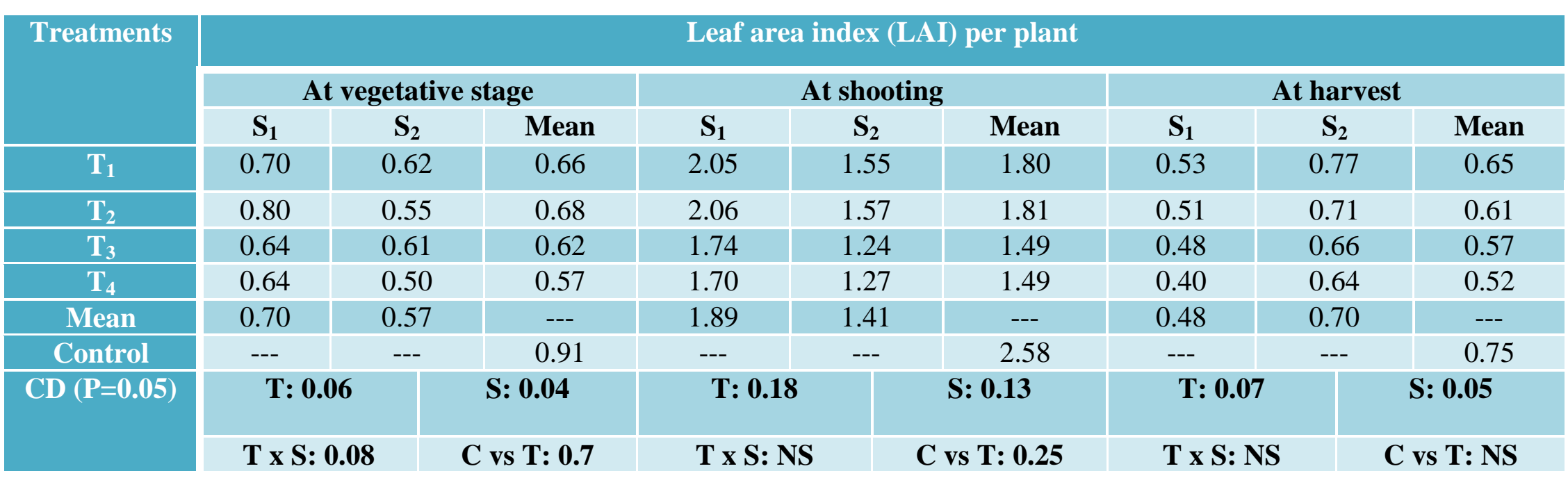

Table.4 Phenological parameters of first ratoon crop

\begin{tabular}{|c|c|c|c|c|c|c|c|c|c|c|c|c|}
\hline \multirow[t]{2}{*}{$\begin{array}{c}\text { Treatment } \\
\text { s }\end{array}$} & \multicolumn{3}{|c|}{ Phyllochron (days) } & \multicolumn{3}{|c|}{$\begin{array}{l}\text { Duration from planting to } \\
\text { first sucker emergence } \\
\text { (days) }\end{array}$} & \multicolumn{3}{|c|}{$\begin{array}{l}\text { Duration from sucker } \\
\text { emergence to shooting of } \\
\text { first ratoon crop (days) }\end{array}$} & \multicolumn{3}{|c|}{$\begin{array}{l}\text { Shooting-harvest } \\
\text { interval (days) }\end{array}$} \\
\hline & $\mathbf{S}_{1}$ & $\mathbf{S}_{\mathbf{2}}$ & Mean & $\mathbf{S}_{1}$ & $\mathbf{S}_{2}$ & Mean & $\mathbf{S}_{1}$ & $\mathbf{S}_{\mathbf{2}}$ & Mean & $\mathbf{S}_{1}$ & $\mathbf{S}_{2}$ & Mean \\
\hline$T_{1}$ & 8.38 & 8.29 & 8.33 & 98.00 & 97.00 & 97.50 & 199.89 & 187.66 & 193.77 & 97.00 & 90.05 & 93.53 \\
\hline $\mathbf{T}_{2}$ & 8.41 & 8.60 & 8.51 & 94.33 & 92.33 & 93.33 & 201.55 & 194.40 & 197.98 & 95.16 & 92.83 & 94.00 \\
\hline$T_{3}$ & 9.05 & 8.73 & 8.89 & 95.67 & 90.67 & 93.17 & 208.50 & 190.77 & 199.64 & 92.58 & 91.33 & 91.96 \\
\hline $\mathrm{T}_{4}$ & 9.53 & 8.77 & 9.15 & 97.67 & 95.33 & 96.50 & 210.28 & 187.78 & 199.03 & 92.25 & 90.50 & 91.37 \\
\hline Mean & 8.85 & 8.60 & --- & 96.42 & 93.83 & --- & 205.05 & 190.15 & --- & 94.25 & 91.18 & --- \\
\hline Control & --- & --- & 8.04 & --- & --- & 187.44 & --- & --- & 190.89 & --- & --- & 89.39 \\
\hline \multirow{2}{*}{$\begin{array}{l}\mathrm{CD} \\
(\mathrm{P}=0.05)\end{array}$} & \multirow{2}{*}{$\begin{array}{l}\text { T:NS } \\
\text { S: NS }\end{array}$} & \multirow{2}{*}{\multicolumn{2}{|c|}{$\begin{array}{c}\text { T x S: NS } \\
\text { C vs T: } 0.96\end{array}$}} & T:NS & \multicolumn{2}{|c|}{ T $\times$ S: NS } & T: NS & \multicolumn{2}{|l|}{ S: 5.72} & T: NS & \multicolumn{2}{|c|}{ S: NS } \\
\hline & & & & S: NS & \multicolumn{2}{|c|}{ C vs T: 4.86} & T $x$ S: NS & \multicolumn{2}{|c|}{ C vs T: NS } & $\begin{array}{l}\text { T x S: } \\
\text { NS }\end{array}$ & \multicolumn{2}{|c|}{ C vs T: NS } \\
\hline
\end{tabular}


Table.5 Phenological parameters of first ratoon crop

\begin{tabular}{|c|c|c|c|c|c|c|c|c|c|c|c|c|c|c|c|}
\hline \multirow[t]{2}{*}{$\begin{array}{l}\text { Treatmen } \\
\text { ts }\end{array}$} & \multicolumn{3}{|c|}{$\begin{array}{c}\text { Duration from } \\
\text { harvesting of first crop } \\
\text { to harvesting of first } \\
\text { ratoon crop }\end{array}$} & \multicolumn{3}{|c|}{$\begin{array}{l}\text { Crop duration (days) of } \\
\text { first crop }\end{array}$} & \multicolumn{3}{|c|}{$\begin{array}{l}\text { Crop duration (days) of } \\
\text { first ratoon crop }\end{array}$} & \multicolumn{3}{|c|}{$\begin{array}{l}\text { Number of fingers per } \\
\text { bunch }\end{array}$} & \multicolumn{3}{|c|}{$\begin{array}{l}\text { Number of hands } \\
\text { per bunch }\end{array}$} \\
\hline & $\mathbf{S}_{1}$ & $\mathbf{S}_{2}$ & Mean & $\mathbf{S}_{1}$ & $\mathbf{S}_{\mathbf{2}}$ & Mean & $\mathbf{S}_{1}$ & $\mathbf{S}_{2}$ & Mean & $\mathbf{S}_{1}$ & $\mathbf{S}_{\mathbf{2}}$ & Mean & $\mathbf{S}_{1}$ & $\mathbf{S}_{2}$ & Mean \\
\hline$T_{1}$ & 77.34 & 68.50 & 72.92 & 317.55 & 306.22 & 311.89 & 296.89 & 277.72 & 30 & 89.75 & 92.75 & & 7.08 & 7.27 & 7.18 \\
\hline $\mathbf{T}_{2}$ & 69.61 & 69.23 & 69.42 & 308.77 & 310.33 & 309.55 & 296.71 & 287.23 & 291.97 & 86.74 & 89.50 & & 6.61 & 7.06 & 6.83 \\
\hline$T_{3}$ & 77.37 & 73.44 & & 321.05 & 299.33 & & 301.08 & 282.10 & & 83.87 & 87.94 & & 6.35 & 6.75 & 6.55 \\
\hline$\overline{T_{4}}$ & 95.20 & 79.18 & 87.19 & 304.99 & 294.43 & 299.71 & 302.53 & 278.28 & 290.40 & 82.00 & 87.36 & 84.68 & 6.25 & 6.67 & 6.46 \\
\hline Mean & 79.88 & 72.59 & --- & 313.09 & 302.58 & --- & 299.30 & 281.33 & --- & 85.59 & 89.39 & --- & 6.57 & 6.94 & --- \\
\hline Control & --- & --- & 159.95 & --- & --- & 307.77 & --- & --- & 280.28 & --- & --- & 93.72 & --- & --- & 7.59 \\
\hline \multirow{2}{*}{$\begin{array}{l}\mathrm{CD} \\
(P=0.05)\end{array}$} & T:NS & \multicolumn{2}{|c|}{ T x S: NS } & T:NS & \multicolumn{2}{|c|}{ T x S: NS } & T:NS & \multicolumn{2}{|c|}{ T x S: NS } & $\mathrm{T}: 3.88$ & \multicolumn{2}{|c|}{ T x S: NS } & T:0.40 & \multicolumn{2}{|c|}{ T x S: NS } \\
\hline & S: NS & \multicolumn{2}{|c|}{ C vs T:29.88 } & S: NS & \multicolumn{2}{|c|}{ C vs T:NS } & S: NS & \multicolumn{2}{|c|}{ C vs T:NS } & S: 2.74 & \multicolumn{2}{|c|}{ C vs T:0.51 } & S: 0.28 & \multicolumn{2}{|c|}{ C vs T:NS } \\
\hline
\end{tabular}

Table.6 Yield attributing Characters

\begin{tabular}{|c|c|c|c|c|c|c|c|c|c|c|c|c|}
\hline \multirow[t]{2}{*}{ Treatments } & \multicolumn{3}{|c|}{$\begin{array}{c}\text { Bunch weight (kg/plant) } \\
\text { of first crop }\end{array}$} & \multicolumn{3}{|c|}{$\begin{array}{l}\text { Bunch weight (kg/plant) of } \\
\text { first ratoon crop }\end{array}$} & \multicolumn{3}{|c|}{ Yield (t/ha) of first crop } & \multicolumn{3}{|c|}{ Yield ( $t /$ ha) of first ratoon } \\
\hline & $\mathbf{S}_{1}$ & $\mathbf{S}_{\mathbf{2}}$ & Mean & $\mathbf{S}_{1}$ & $\mathbf{S}_{2}$ & Mean & $\mathbf{S}_{1}$ & $\mathbf{S}_{2}$ & Mean & $\mathbf{S}_{1}$ & $\mathbf{S}_{\mathbf{2}}$ & Mean \\
\hline $\mathbf{T}_{1}$ & 9.23 & 10.04 & 9.63 & 8.71 & 9.41 & 9.06 & 20.93 & 16.05 & 18.49 & 19.73 & 15.05 & 17.39 \\
\hline$\overline{T_{2}}$ & 8.53 & 9.45 & 8.99 & 6.28 & 8.24 & 7.26 & 19.33 & 15.11 & 17.22 & 14.67 & 13.18 & 13.93 \\
\hline $\mathbf{T}_{3}$ & 8.34 & 9.21 & 8.77 & 6.22 & 7.49 & 6.85 & 18.91 & 14.73 & 16.82 & 14.09 & 11.97 & 13.03 \\
\hline $\mathbf{T}_{4}$ & 7.24 & 8.38 & 7.81 & 6.16 & 6.33 & 6.24 & 16.42 & 13.40 & 14.91 & 14.33 & 10.12 & 12.23 \\
\hline Mean & 8.34 & 9.27 & --- & 6.84 & 7.87 & --- & 18.90 & 14.82 & --- & 15.71 & 12.58 & --- \\
\hline Control & --- & --- & 9.76 & --- & --- & 10.08 & --- & --- & 22.12 & --- & --- & 22.84 \\
\hline \multirow[t]{2}{*}{$\mathrm{CD}(\mathrm{P}=0.05)$} & T:0.73 & \multicolumn{2}{|c|}{ S: 0.51} & T:0.29 & \multicolumn{2}{|c|}{ T x S: 0.41} & $\mathrm{~T}: 1.43$ & \multicolumn{2}{|c|}{ S: 1.01} & T: 0.66 & \multicolumn{2}{|c|}{ S: 0.46} \\
\hline & T $x$ S: NS & \multicolumn{2}{|c|}{ C vs T: NS } & S: 0.21 & \multicolumn{2}{|c|}{ C vs T: 0.35} & T $x$ S: NS & \multicolumn{2}{|c|}{ C vs T: 1.24} & T x S: 0.93 & \multicolumn{2}{|c|}{ C vs T: 0.71} \\
\hline
\end{tabular}


Though there was no significant difference among the treatments but the phyllochorn gradually increased with increase in the number of suckers per plant. Leaf emergence is normally reported to be at slower rate under very closer planting owing to low temperature experienced inside the canopy as temperature has greater influence on leaf production (Robinson and Nel, 1989). Phyllochron in plants under control was lowest (8.04 days) and differed significantly from the values of the treatments and resulted earlier shooting of the plants. The lowest phyllochron in the lowest plant population might be due to frequent unfurling of leaves. The duration from planting to first sucker emergence ranged from 90.67 days to 98.0 days in different treatment combinations and there were no significant influence treatments or spacing. This might be due to the selection and planting of uniform size suckers. On the other hand, desuckering was followed in the plants under control as per recommended practice and only one sucker was allowed to continue its growth when the mother plants came into shooting. Therefore, the duration from planting to first sucker retention was 187.44 days in plants under control under the investigation.

Days taken to shooting from sucker emergence and shooting-harvest interval delayed with the increase in number of suckers with the mother plants due to competition pressure exerted by the suckers to its mother plant. Days taken from first sucker emergence to shooting (199.64 days in $\mathrm{T}_{3}$ ) and shooting to harvest ( 94.0 days in $\mathrm{T}_{2}$ ) were longest when suckers were retained with mother plants whereas these duration were shortest (190.89 days and 89.39 days, respectively) when no suckers were retained till shooting (control). Chattopadhyay et al., (1980) reported that shooting was delayed with increased plant population in both plant and ratoon crop.
It was observed that duration for shooting was shorter in wider spacing $\left(\mathrm{S}_{2}\right)$ than recommended spacing (closer spacing than $\mathrm{S}_{2}$ ). This might be due to the more exposure of leaf surfaces to light in wider spacing which increased the metabolism of the plants causing early physiological maturity and flowering. Delayed shooting due to closer spacing was also reported by Stover (1979).

The average crop duration decreased with the increase in planting density both in first crop and in first ratoon crop. However, there was no significant effect of treatments and spacing on crop duration. The result of the present investigation gets support from the research of Chundawat et al., (1982). It was interesting to note that the treatments which took shorter time for shooting recorded the shorter duration of crop cycle. But the result of Hazarika (2001) revealed that 'Malbhog' banana required longest duration for shooting (280.82 days) and harvesting from shooting (112.08 days). It might be due to the difference in location, time of planting, climatic condition such as temperature, sunshine, rainfall and relative humidity during the cropping period.

Number of hands and fingers per bunch produced by the plants are developed at very young stage of the plant before shooting in the soil level itself and depends on growth of the plant, nutrient status in soil, soil moisture and among the most important factors in the prevailing temperature (Chakrabarty, 1977).

In the present study, number of hands and fingers per bunch were highest in plants with one sucker $\left(\mathrm{T}_{1}\right)$ and lowest in plants with four suckers $\left(\mathrm{T}_{4}\right)$. It might be concluded that in wider spacing $\left(\mathbf{S}_{2}\right)$ the plants were more exposed to the solar energy which encouraged more carbohydrate synthesis in plants resulting higher number of hands and fingers per bunch. 
The economic character of a banana plant is the bunch which is influenced by the number of hands and fingers per bunch. The result of the present study revealed that number of hand and fingers, bunch weight and yield were significantly influenced by the different treatments in both first crop and first ratoon crop. Among the different treatments, bunch weight per plant and corresponding yield per hectare were highest in plants with retention of only one sucker with mother plant $\left(\mathrm{T}_{1}\right)$ and bunch weight and yield gradually decreased with the increase in number of suckers per plant.

It could also be associated with the higher number of hands and fingers per bunch recorded in this treatment. It was interesting to note that though the bunch weight per plant was found to be higher in wider spacing but the total yield per hectare was reduced in wider spacing. It might be due more number of plants accommodated per unit area with closer spacing $\left(S_{1}\right)$. Similar results were also obtained by Abdullah et al., (2010).

The plants cultivated as per recommended package of practices (control) produced the heaviest bunches which might be due to adequate spacing, plant population and nutrient supply resulting higher values of number of hands and number of fingers per bunch.

The highest benefit-cost ratio of $\mathrm{S}_{1} \mathrm{~T}_{1}$ (mother plant +1 sucker in $2.1 \mathrm{~m} \times 2.1 \mathrm{~m}$ ) and $\mathrm{S}_{2} \mathrm{~T}_{1}$ (mother plant +1 sucker in $2.5 \mathrm{~m} \mathrm{x} 2.5 \mathrm{~m}$ ) were 4.75 and 4.74 , respectively and this might be due to higher return obtained from banana and sucker production.

The lowest (2.92) benefit-cost ratio was recorded in the treatment four suckers per hill with a spacing of $2.5 \mathrm{~m} \times 2.5 \mathrm{~m}$. which might be due to higher cost of cultivation as compared to total yield of this treatment.

\section{References}

Abdallah, B. M., Roshdy, K. A. and ElShenawi, M. R. (2010). Effect of plant density on growth, flowering, fruiting and yield of Grand Naine banana in sandy soil. Alex. Sci. Exchange. J., 31: 380-385.

Chakrabarty, B. K. (1977). Certain aspect on growth and development in banana with special reference to flower bud initiation. Ph.D. Thesis, TNAU, Coimbatore.

Chattopadhayay, P. K., Chattopadhayay, S., Maiti, S. C. and Bose, T. K. (1980). Effect of plant density on growth, yield and quality of banana. Nat. sem. Banana Prod. Tech. TNAU, Coimbatore. pp. 79-89.

Chaudhuri, P. and Baruah, K. (2010). Studies on Planting Density in Banana cv. 'Jahaji' (AAA). Indian Journal of Hill Farming, 23(2):31-38.

Chundawat, B. S., Dove, S. K. and Pateln, N. L. (1982). High density plantation in relation to yield and quality in Basrai banana. South Indian Hort. 30:175-177.

Gogoi, B., Khangia, B., Baruah, K. and Khound, A. (2015). Effect of High Density Planting and Nutrient Management on Growth and Yield of Banana cv. Jahaji (Musa, AAA). Int. J. Agric. Innovations and Res., 3:14651469.

Hidoto, L. (2009). Effect of sucker management on banana yield. Afr. Crop Sci. Confer. Proc., 9:275 - 277.

Mahdi, E. F. M., Bakhiet, S. B. and Gasim, S. (2014). Growth and yield responses of banana plant to desuckering practice. Int. J. Science Environ. Techno, 3:279285.

Purseglove, J. W. (1976). Soil and Plant Analysis. Hans. Pub. Bombay 3rd Edn.: 49-54. 
Robinson, J. C. and Nel, D. J. (1989a). Plant density studies with banana (cv. Williams) in sub-tropical climate. I. vegetative morphology, phenology and plantation micro-climate. J. Hort. Sci., 64(4):513-519.

Robinson, J. C., Anderson, T. and Eckstein, K. (1992). The influence of functional leaf removal at flower emergence on components of yield and photosynthetic compensation in banana. J. Hort. Sci., 67(3):403-410.

Sarrwy, S. M. A., Mostafa, E. A. M. and Hassan, H. S. A. (2012). Growth, Yield and Fruit Quality of Williams Banana as Affected by Different Planting Distances. Int. J. Agric. Res., 7:266-275.

Seifu, G. (2003). Status of Commercial Fruit Production in Ethiopia. Ethiopia Agricultural Research Organization, Addis Ababa, Ethiopia.

Simmonds, N. W. (1966). Bananas. 2nd edition. Longmans, London.

Stover, R. H. (1979). Pseudostem growth, leaf production and flower initiation in the 'Grand Naine' banana. Bull. Trop. Agric. Services., 8:37. (Hort. Abstr. 50:9622).

\section{How to cite this article:}

Rupshree Borah, Dharindra Nath Hazarika, Supriya Langthasa and Dorodi Priyam Duarah. 2018. Effect of Number of Suckers per Hill on Growth and Yield of Banana cv. Malbhog (AAB) in Ratoon Crop. Int.J.Curr.Microbiol.App.Sci. 7(10): 1812-1820. doi: https://doi.org/10.20546/ijcmas.2018.710.207 